\title{
Production of $\alpha$-amylase from Aspergillus flavus S2-OY using solid substrate fermentation of potato (Solanum tuberosum L.) peel
}

\author{
Victor Olumide OLAKUSEHIN and Olaoluwa OYEDEJI*
}

Department of Microbiology, Faculty of Science, Obafemi Awolowo University, Ile-Ife, Nigeria.

*Corresponding author; E-mail: laoluoyedeji@gmail.com, Phone: +234 8033745381

\begin{abstract}
\begin{tabular}{lll}
\hline Received: 17-05-2021 & Accepted: 28-09-2021 & Published: 30-10-2021 \\
\hline
\end{tabular}
ABSTRACT

Amylases find commercial applications in diverse industries. This study investigated the production of $\alpha$-amylase from a fungus, using potato peel as an alternative substrate. Six fungal isolates from the soil of cassava waste dumpsite were tentatively identified as two Aspergillus species and one species each of Rhizopus, Trichocladium, Neosartorya and Ascodermis. They were screened for their relative amylolytic activities using the starch agar hydrolysis test. Molecular characterization, using the ITS rRNA gene sequencing, was used to confirm the identity of the selected fungus as Aspergillus flavus S2-OY. Amylase production from the fungus via solid substrate fermentation of potato peel was carried out and the effect of production parameters investigated. Maximum $\alpha$-amylase production was at an incubation period of $72 \mathrm{~h}, \mathrm{pH}$ of 5.0 and temperature of $25{ }^{\circ} \mathrm{C}$. Casein and maltose were the best nitrogen and carbon sources, respectively while the optima inoculum and moisture volumes for enzyme production were $1.5 \mathrm{~mL}$ and $5.0 \mathrm{~mL}$, respectively. Aspergillus flavus S2-OY has great potential for $\alpha$-amylase production using potato peel as an alternative and cheap substrate, under solid substrate fermentation condition. This has implications for the cost-effective production of an industrial enzyme and reduction of environmental pollution problems through effectual management of agro-industrial wastes. (C) 2021 International Formulae Group. All rights reserved.
\end{abstract}

Keywords: Aspergillus flavus, $\alpha$-amylase, optimization, solid substrate fermentation, potato peel, agricultural waste.

\section{INTRODUCTION}

Alpha-amylase (EC 3.2.1.1), also known as endo-1,4- $\alpha$-d-glucanohydrolase, is an extracellular enzyme that randomly cleaves the 1,4- $\alpha$-D-glycosidic bonds holding adjacent glucose molecules together, in a linear amylose chain in starch, thereby producing a range of products such as glucose, maltose and other oligosaccharides (Maity et al., 2015). Thus, the primary substrate of the enzyme is starch, which is one of the most abundantly distributed polysaccharides produced by plants, through the process of photosynthesis. Apart from $\alpha-$ amylase, other enzymes with the ability for starch degradation are $\beta$-amylase, glucoamylase, isoamylase and pullulanase (Hill et al., 2012).

Although, $\alpha$-amylases are produced by plants, animals and microorganisms, the enzyme production from microorganisms are 
preferred for commercial purpose due to benefits such as low cost, reliability, stability, less time and space needed for enzyme production (Simair et al., 2017). Therefore, the majority of industrial and biotechnological applications are derived from particular fungi and bacteria.

Alpha amylases are one of the most important enzymes in the field of biotechnology and enjoy approximately, 25\% of the world enzyme market (Reddy et al., 2003) They find applications in various industries such as textile, confectionary, baking, brewing, sugar, alcohol, paper coating, starch, pharmaceutical and syrup industries (Oyeleke et al., 2013). Other uses include the use as digestive aid, detergents and for sewage treatment (Dhanya et al., 2009).

Fruit and vegetable wastes resulting from agricultural and industrial processing, account for 30 to $50 \%$ of the input materials (Di Donato et al., 2011). The wastes are mostly generated from preliminary operations such as peelings and cuttings. Enormous amount of these wastes are disposed into the environment resulting into pollution hazards which are detrimental to its biological and physical components. Potato (Solanum tuberosum L.) is a major cash crop produced and sold all over the world. As a result of the processing of potato (Solanum tuberosum L.) into various products in industries, a lot of wastes are generated, chief amongst them is the potato peel, which is an epicarp covering of the potato root shielding its flesh (Shukla and Kar, 2006). These potato peels create severe disposal problems in industries as they are mostly discarded and allowed to rot causing environmental pollution. However, potato peels contain sufficient amount of nutrients for nutritional purposes and pharmacological use. Some these nutrients include dietary fiber, antioxidants, phenolic compounds, vitamins and minerals, and also cell wall could be used as substrates for fungal growth and $\alpha$-amylase production (Shukla and Kar, 2006; Schieber et al., 2009). Increasing $\alpha$-amylase production demands, high nutrient cost and environmental concerns have stimulated interest in the utilization of agrowastes as cost-effective substrates for production of the enzyme. Several agrowastes such as banana peels (Khan and Yadav, 2011), date wastes (Acourene and Ammouche, 2012), sugarcane baggase (Roses and Guerra, 2009) and rice husks (Oyeleke et al., 2013) were investigated as cost-effective substrates for $\alpha$-amylase production.

Aspergillus species are useful microorganisms in food fermentations and biotechnological applications (Varga and Samson, 2008). Several strains of the species have been implicated in $\alpha$-amylase production (Chimata et al., 2010; Kirankumar et al., 2011; Ajayi et al. 2014; Sethi et al., 2016). Optimization of fermentation parameters such as $\mathrm{pH}$, temperature, incubation period, carbon and nitrogen sources, is one of the approaches employed for the achievement of high enzyme yield during the process (Sethi et al., 2017).

Alpha amylases are generally produced by using the submerged fermentation technique. However, lately, solid substrate fermentation method is gradually being utilized for this purpose (Xu et al., 2008; Zambare, 2010), due to advantages such as simple technique, superior and high volumetric productivity, low capital investment, low catabolite repression, marginal end-product inhibition, low energy requirement, simple fermentation equipment requirement, less water output and better product recovery (Ferreria et al., 2015).

The aim of this study was to optimize $\alpha$-amylase production from Aspergillus flavus S2-OY under solid substrate fermentation condition, using potato peel as an alternative substrate. This was with a view for costeffective production of this industrial enzyme and reduction of environmental pollution problems associated with the indiscriminate dumping of potato wastes. 


\section{MATERIALS AND METHODS}

\section{Fungal isolation and culture maintenance}

Fungi were isolated from soil samples collected from the soil of cassava waste dumpsite. Distinct fungal growth on potato dextrose agar (PDA) plates were successively sub-cultured on fresh medium to obtain pure colonies. The pure fungal colonies were then maintained on potato dextrose agar (PDA) slants and stored at $4{ }^{\circ} \mathrm{C}$.

\section{Screening of fungal isolates for $\alpha$-amylase production}

The isolated fungi were screened for their relative $\alpha$-amylase production capacity using the starch agar plate assay method of Ugo and Ijigbade (2013). The isolate with the highest zone of clearance was selected for further studies and maintained on potato dextrose agar slant at $4{ }^{\circ} \mathrm{C}$.

\section{Characterization and identification of fungal isolates}

The isolated fungal isolates were characterized macroscopically and microscopically. The fungal morphology was studied macroscopically by observing their features on plate such as surface colour, margin, form, texture and diameter. Microscopic characterization was carried out using a compound binocular microscope to view the lactophenol cotton blue-stained slides mounted with a small portion of the mycelium. The characteristics observed were the spore type and shape, type of sporangia and type of hyphae (Gaddeyya et al., 2012). Molecular characterization was then carried out to confirm the identity of the selected fungus. This was based on the analysis of internal transcribed spacer (ITS) region of the ribosomal DNA gene (White et al. 1990). Fungal genomic DNA was extracted from 5day old fungal culture with the aid of the ZR Fungal/Bacterial DNA MiniPrep kit (ZYMO RESEARCH, USA). Primers ITS 4 (F, 5'TCCTCCGCTTATTGATATGS-3') and ITS 5
(R, 5'-GGAAGTAAAAGTCGTAACAAGG-

3') were used to amplify the ribosomal gene. Amplification was carried out in a thermal cycler (Applied Biosystems) with reaction conditions: initial denaturation at $94{ }^{\circ} \mathrm{C}$ for 5 $\mathrm{min}$, followed by 36 cycles of denaturation at $94{ }^{\circ} \mathrm{C}$ for $30 \mathrm{~s}$, annealing at $54{ }^{\circ} \mathrm{C}$ for $30 \mathrm{~s}$, elongation at $72{ }^{\circ} \mathrm{C}$ for $45 \mathrm{~s}$ and followed by a final elongation at $72{ }^{\circ} \mathrm{C}$ for $7 \mathrm{~min}$ and hold temperature at $10{ }^{\circ} \mathrm{C}$. The amplified fragments were sequenced using a Genetic Analyzer 3130xl sequencer (Applied Biosystems.

\section{Collection and preparation of agricultural wastes}

Cassava (Manihot esculenta Crantz), potato (Solanum tuberosum L.) and yam (Dioscorea rotundata) peels were obtained from their respective processing sites in Ile-Ife, Nigeria. They were shredded and prepared by exhaustive washing with distilled water, ovendried at a temperature of $60^{\circ} \mathrm{C}$ for 1 week until they were well dried. Thereafter, the peels were milled and sieved into $0.5 \mathrm{~mm}$ particle sizes with milling machine. They were stored in clean, dried, airtight containers and kept in the refrigerator at $4{ }^{\circ} \mathrm{C}$ and were subsequently used as substrate in enzyme fermentation media (Ahmed et al., 2016).

\section{Screening of agricultural wastes as substrate for $\alpha$-amylase production}

The powdered agricultural waste residues potato, yam and cassava peels were screened for their suitability as substrate for fungal growth and $\alpha$-amylase production, under solid substrate fermentation condition The crude enzyme was assayed for $\alpha$-amylase activity. The agricultural waste which produced the highest activity was selected for use as substrate in the enzyme production process.

\section{Proximate analysis of potato peel}

Potato peel was selected due to its huge potential in supporting fungal growth and $\alpha$ - 
amylase production. The peel was chemically and nutritionally analyzed. The total carbohydrate, crude protein, lipid, crude fibre, moisture and ash contents were determined using the method described by AOAC (2005).

\section{Alpha amylase production}

Alpha amylase production using the solid-substrate fermentation technique was carried-out according to the modified method of Singh et al. (2009). The fermentation medium used for the production process contained $5 \mathrm{~g}$ of raw potato peel powder amended with $10 \mathrm{~mL}$ of minimal salt solution. The minimal salt solution contained the following; $\mathrm{KH}_{2} \mathrm{PO}_{4} 2.0$ (g/l), $\mathrm{MgSO}_{4} .7 \mathrm{H}_{2} \mathrm{O} 0.2$ (g/l), $\mathrm{NaCl} 0.1(\mathrm{~g} / \mathrm{l}), \mathrm{CaCl}_{2} \mathrm{O} .1(\mathrm{~g} / \mathrm{l})$ and $\mathrm{MnSO}_{4}$ $0.5(\mathrm{~g} / \mathrm{l})$ and peptone $0.2(\mathrm{~g} / \mathrm{l})$ at $\mathrm{pH}$ 6.0. The culture medium was prepared in a series of 100 $\mathrm{ml}$ cotton-plugged Erlenmeyer flasks, homogenously mixed and sterilized at $121{ }^{\circ} \mathrm{C}$ for $15 \mathrm{~min}$ in an autoclave. Thereafter, the flasks were cooled at room temperature and each inoculated with $1.0 \mathrm{ml}$ standardized fungal spore suspension $\left(5.0 \times 10^{5}\right.$ spores $\left./ \mathrm{ml}\right)$ of Aspergillus sp. under sterile condition, with the aid of sterile pipette. The flasks were then incubated at $30{ }^{\circ} \mathrm{C}$ for 5 days. At the end of fermentation, the fermented mass was mixed with $50 \mathrm{~mL}$ distilled water and agitated on a rotary shaker at $150 \mathrm{rpm}$ for a period of $1 \mathrm{~h}$. It was filtered using Whatman filter paper No. 1 and the filtrate was then centrifuged at 6000 rpm for $15 \mathrm{~min}$. The cell-free supernatant was collected as crude enzyme for subsequent analysis.

\footnotetext{
Alpha amylase assay

$\alpha$-Amylase activity was determined by estimating the amount of reducing sugars released in a reaction mixture containing $1.0 \mathrm{ml}$ soluble starch in phosphate buffer, $\mathrm{pH} 6.0$ and $1.0 \mathrm{ml}$ of enzyme extract, according to the DNSA assay method as described by Miller (1959). Incubation was done at $50{ }^{\circ} \mathrm{C}$ in a water-bath for $10 \mathrm{~min}$ after which the reaction
}

was terminated with $1.0 \mathrm{ml}$ dinitrosalicylic acid (DNSA) reagent and the mixture boiled for 15 min. The test tubes were allowed to cool down and the absorbance read at $540 \mathrm{~nm}$ using a UV spectrophotometer. The concentration of the glucose released was read against the glucose standard. One unit (U) of enzyme activity was described as the amount of enzyme that released $\mu$ mole of reducing sugar per minute per millilitre, under assay conditions.

\section{Optimization of $\alpha$-amylase production Effect of incubation period on a-amylase production}

This was carried out by using the method described by Puri et al. (2013). The effect of incubation period on $\alpha$-amylase production and fungal growth, the fermentation medium was inoculated with selected fungus and incubated for 7 days. The flasks were incubated at $30^{\circ} \mathrm{C}$ and was sampled every $24 \mathrm{~h}$ and assayed for enzyme production and the fungal growth estimated.

\section{Effect of $p H$ on production of a-amylase}

The effect of $\mathrm{pH}$ on $\alpha$-amylase production was determined by adjusting the $\mathrm{pH}$ of the fermentation medium to different levels 3.0 to 8.0. Thereafter, each flask containing the varied $\mathrm{pH}$ medium was inoculated with fungal spore suspension incubated for $72 \mathrm{~h}$ at $30{ }^{\circ} \mathrm{C}$. After incubation, the enzyme activity was assayed.

\section{Effect of temperature on production of $\alpha$ - amylase}

The influence of temperature on $\alpha$ amylase production was studied using a modified method of Puri et al. (2013). This was carried out by subjecting the fermentation medium to different temperature range $20^{\circ} \mathrm{C}$ to $45^{\circ} \mathrm{C}$. The cell-free supernatant was obtained and enzyme production determined.

\section{Effect of carbon sources on production of $\alpha$ - amylase}

Different carbon sources - fructose, soluble starch, sucrose, glucose, lactose, maltose, and potato peel were investigated as 
carbon sources for enzyme production. After incubation, the enzyme was extracted and the activity determined.

\section{Effect of nitrogen sources on a-amylase production}

The effect of different nitrogen sources, on $\alpha$-amylase, were studied. These included casein hydrolysate, yeast extract, gelatin, tryptone, peptone, urea, ammonium nitrate and potassium nitrate. After incubation, the enzyme extract was assayed for its activity.

\section{Effect of inoculum sizes on a-amylase production}

The modified method of Puri et al. (2013) was used in studying the effect of inoculum sizes on $\alpha$-amylase production. The fermentation medium was prepared and inoculated with different inoculum sizes $0.5 \mathrm{ml}$ to $2.0 \mathrm{ml}$. After incubation, enzyme was extracted and assayed for its activity.

\section{Effect of moisture on a-amylase production}

The effect of moisture content on $\alpha$ amylase production was studied. Different volumes of mineral salt solution used varied from 2.5 to $15.0 \mathrm{ml}$. The enzyme extract was assayed for $\alpha$-amylase activity.

\section{Statistical analysis}

All data were subjected to statistical analysis for determination of mean and standard deviation using SPSS version 16. Experiments were carried out in triplicates.

\section{RESULTS}

\section{Isolation of fungi and screening for $\alpha$ - amylase production}

Six morphologically-distinct strains of fungi were isolated from soil samples collected from the cassava waste dumpsite at Tonkere, Ile-Ife. The isolates were successively subcultured on fresh PDA plates to obtain pure cultures. They were screened for $\alpha$-amylase production using the starch agar hydrolysis assay and the strain Aspergillus sp. 1 with code (S2) exhibiting the largest zone of clearance was taken as that with the highest enzymeproduction ability. It was therefore selected for further studies (Plate 1; Table 1).

\section{Characterization and identification of fungal isolates}

The fungal isolates were characterized based on their morphology on individual plates and under the microscope (i.e macroscopy and microscopy) (Table 2). The fungal isolates were identified based on the phenotypic characterization such as distinctive characters of the arrangement, shapes and sizes of macroand microconidia, presence and absence of chlamydospores as well as cultural appearance and pigmentations on potato dextrose agar medium. They were presumptively identified as two Aspergillus spp., and one species each of Rhizopus, Trichocladium, Neosartorya and Ascodermis. They were respectively maintained on PDA slants and stored at $4{ }^{\circ} \mathrm{C}$. The selected amylolytic fungal isolate Aspergillus sp. 1 was molecularly characterized and identified based on ITS rRNA nucleotide sequencing and comparison to the sequences in NCBI database. The identity of the fungus was confirmed as Aspergillus flavus S2-OY with maximum identity of $97.47 \%$ to other Aspergillus flavus. The isolate was deposited in GenBank as the strain S2-OY (GenBank accession no. MZ267053.1).

\section{Screening of agricultural wastes for $\alpha$ - amylase production from $A$. flavus S2-OY}

Alpha amylase production was achieved with the use of the three agricultural wastes - yam, potato and cassava peels, as substrates, for the solid substrate fermentation. However, potato peel acted as the best substrate for $\alpha$-amylase production with enzyme activity $30.13 \pm 0.65$ Units $/ \mathrm{ml}$. This was followed by the use of yam peel (20.07 \pm 0.64 Units/ml $)$ and cassava peel $(14.60 \pm 0.49$ $\mathrm{ml}$ ) as substrates (Figure 1). 


\section{Proximate analysis of potato peel}

The result of the proximate analysis of potato peel is presented in Table 3. The potato peel contained $7.44 \pm 0.14 \%$ moisture, $4.39 \pm$ $0.17 \%$ ash, $6.16 \pm 0.20 \%$ crude fibre, $9.37 \pm$ $0.04 \%$ ether extract, $15.18 \pm 0.13 \%$ crude protein, $57.56 \pm 0.07 \%$ Nitrogen free extract and $63.91 \pm 0.13 \%$ total carbohydrate.

\section{Optimization of $\alpha$-amylase production from fungus \\ Effect of incubation period on a-amylase production and fungal growth}

The minimum enzyme activity of 41.45 \pm 0.61 Units $/ \mathrm{ml}$ was observed at $24 \mathrm{~h}$. The production increased gradually until it reached a peak at $72 \mathrm{~h}(85.52 \pm 0.50 \mathrm{Units} / \mathrm{ml})$ of the fermentation period. This revealed that the optimum incubation period for $\alpha$-amylase production from the selected fungus was $72 \mathrm{~h}$ of fermentation period whilst still in the exponential phase of fungal growth. Beyond this period, the enzyme production declined. However, the fungal growth increased exponentially with increase in incubation period until $120 \mathrm{~h}$ when it began to decline (Figure 2).

\section{Effect of pH on a-amylase production}

The $\alpha$-amylase activity increased steadily from $\mathrm{pH} 3.0(14.22 \pm 0.57$ Units $/ \mathrm{ml})$ until it reached a peak at $\mathrm{pH} 5.0(40.07 \pm 0.45$ Units/ml). Thus, the optimum $\mathrm{pH}$ for the enzyme production was found to be 5.0. However, at $\mathrm{pH}$ values above this, there was a gradual reduction in $\alpha$-amylase production (Figure 3).

\section{Effect of temperature on a-amylase production}

Alpha-amylase activity and production from A. flavus S2-OY increased from $20.49 \pm$ 0.43 Units $/ \mathrm{mL}$ at $20{ }^{\circ} \mathrm{C}$ incubation temperature to reach maximum at $25^{\circ} \mathrm{C}(30.21$ \pm 0.50 Units $/ \mathrm{ml}) . \alpha$-Amylase production then decreased with increase in temperature down to a minimum value of $3.95 \pm 0.37 \mathrm{Units} / \mathrm{ml}$ at 45 ${ }^{\circ} \mathrm{C}$ (Figure 4).

Effect of inoculum size on a-amylase production

Alpha-amylase production from $A$. flavus S2-OY, under solid substrate fermentation condition, was maximum when an inoculum size of $1.5 \mathrm{ml}(79.03 \pm 0.97$ Units $/ \mathrm{ml}$ ) was used in the fermentation medium. $\alpha$-Amylase production then decreased as inoculum size increased to $2.0 \mathrm{ml}(60.04 \pm$ 0.95 Units/ml (Figure 5).

\section{Effect of moisture on $\alpha$-amylase production}

The effect of moisture on $\alpha$-amylase production was also studied. Results revealed that the enzyme was most produced when the volume of $5.0 \mathrm{ml}$ minimal salt solution $(78.2 \pm$ 0.68 Units $/ \mathrm{ml}$ ) was used for fermentation. Moisture volumes below and above this gave lesser enzyme production. Thus, the best moisture volume for $\alpha$-amylase production from the fungus was $5.0 \mathrm{ml}$ (Figure 6).

Effect of carbon sources on a-amylase production

Alpha-amylase production was maximum with the use of maltose as carbon source $(66.25 \pm 0.78$ Units $/ \mathrm{ml})$. This was followed by the use of soluble starch $(53.07 \pm$ 0.73 Units $/ \mathrm{ml})$ and potato peel $(48.14 \pm 0.43$ Units $/ \mathrm{ml}$ ) as carbon sources, while the lowest $\alpha$-amylase production was achieved with the use of sucrose $(26.98 \pm 0.53$ Units $/ \mathrm{ml})$ as carbon source for $\alpha$-amylase production, under the solid substrate fermentation condition (Figure 7).

Effect of nitrogen sources on a-amylase production

Alpha amylase production from $A$. flavus S2-OY was maximum $(76.290 .78$ Units/ml) with the use of casein as nitrogen source. This was followed by the use of potassium nitrate $(38.63 \pm 0.50$ Units $/ \mathrm{ml})$ as nitrogen source while the lowest activity was achieved with the use of gelatin (21.44 \pm 0.68 Units $/ \mathrm{ml}$ ) as nitrogen source (Figure 8). 


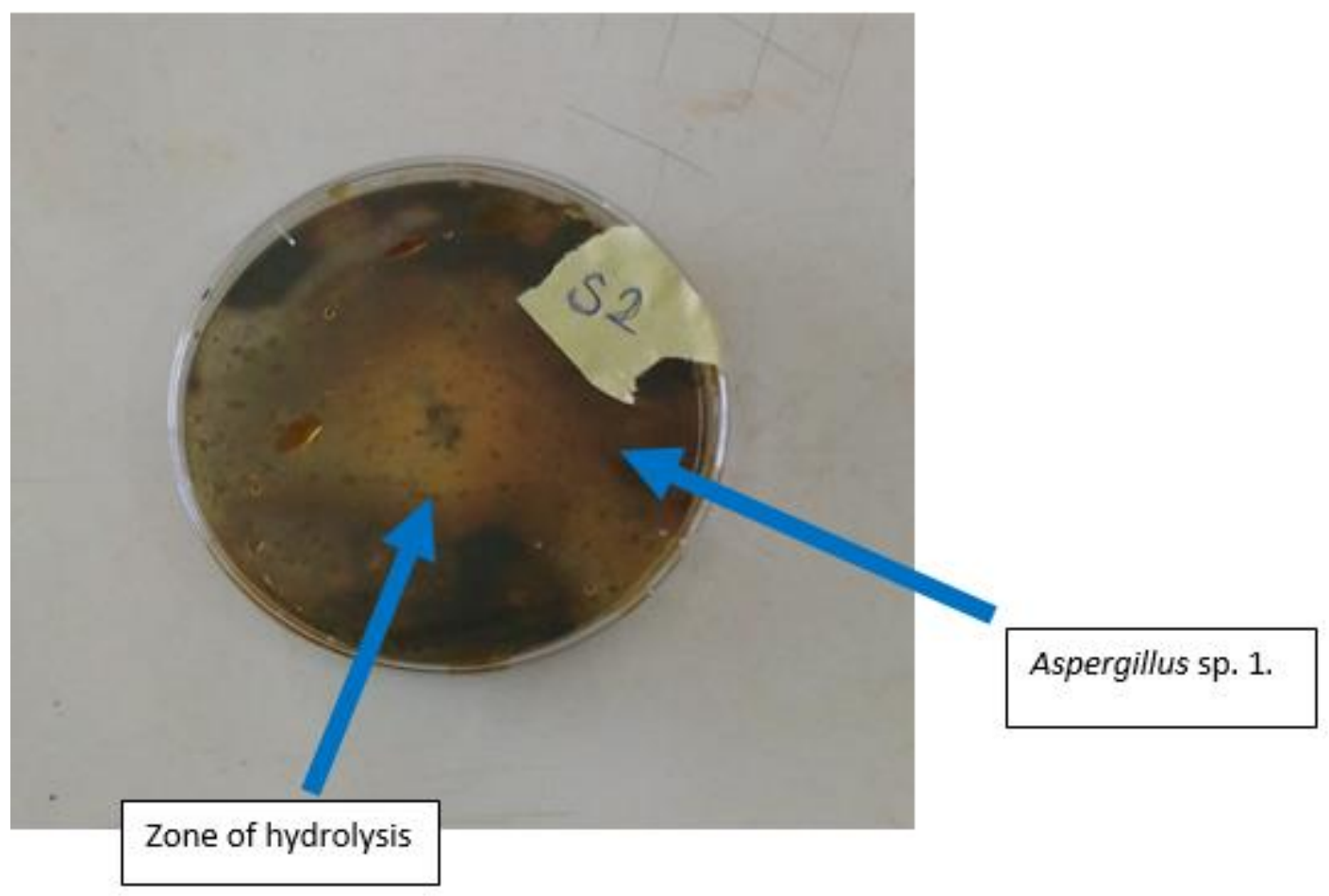

Plate 1 Zone of hydrolysis of leading Aspergillus sp. 1 on PDA plate at $30^{\circ} \mathrm{C}$, pH 5.6 after 5 days of incubation.

Table 1: Screening of fungal isolates for $\alpha$-amylase-production by the starch hydrolysis plate assay.

\begin{tabular}{lll}
\hline Isolate code & Fungal isolate & Halo zone diameter $(\mathbf{m m})$ \\
\hline S1 & Neosartorya sp. & $2.39 \pm 0.01$ \\
S2 & Aspergillus sp.1 & $5.16 \pm 0.04$ \\
S3 & Trichocladium sp. & $3.48 \pm 0.03$ \\
S4 & Rhizopus sp. & $3.63 \pm 0.08$ \\
S5 & Aspergillus sp. & $3.52 \pm 0.02$ \\
S6 & Ascodermis $\mathrm{sp}$. & $2.76 \pm 0.06$ \\
\hline
\end{tabular}


Table 2: Phenotypic characterization and identification of fungal isolates.

\begin{tabular}{|c|c|c|}
\hline Isolate & Microscopic features & $\begin{array}{l}\text { Presumptive } \\
\text { Identification }\end{array}$ \\
\hline S1 & $\begin{array}{l}\text { Upright conidiosphore, terminating in a globose, radiating from the entire } \\
\text { surface, I-celled. }\end{array}$ & Neosartorya sp. \\
\hline $\mathrm{S} 2$ & $\begin{array}{l}\text { Very long, thick, straight and upright conidiophores. Enlarged at the } \\
\text { apex, radiating conidia from surface. Globose, ovoid, simple, bearing } \\
\text { phialides at the head attached with conidia. }\end{array}$ & Aspergillus sp. 1 \\
\hline S3 & Conidiophores poorly developed, ovoid, septate. & Trichocladium sp. \\
\hline S4 & $\begin{array}{l}\text { Long conidiophores, bearing stolons, rhizoids, clustered apex with ripe } \\
\text { conidia. }\end{array}$ & Rhizopus sp. \\
\hline S5 & $\begin{array}{l}\text { Long, thick, upright conidiosphore arising from the mycelium singly. } \\
\text { Conidia head with phialides attached to it at its apex, I-celled, globose. }\end{array}$ & Aspergillus sp. 1 \\
\hline S6 & $\begin{array}{l}\text { Ditch shape format, ovoid, globose, cluster conidia covered with a } \\
\text { membrane. }\end{array}$ & Ascodermis sp. \\
\hline
\end{tabular}

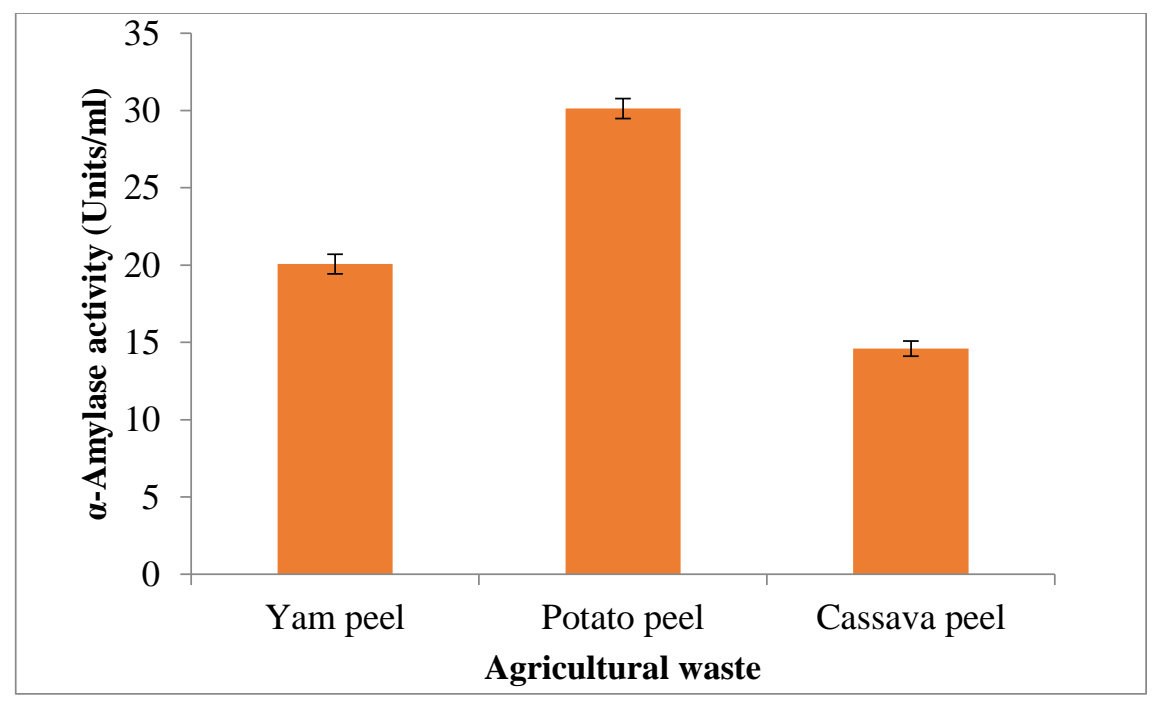

Figure 1: Screening of agricultural wastes as substrate for $\alpha$-amylase production from A. flavus S2OY.

Table 3: Proximate analysis of potato peel.

\begin{tabular}{ll}
\hline Nutrient & Percentage Composition (\%) \\
\hline Ash & $4.39 \pm 0.17$ \\
Moisture & $7.44 \pm 0.14$ \\
Crude fibre & $6.16 \pm 0.20$ \\
Ether extract & $9.37 \pm 0.04$ \\
Crude protein & $15.18 \pm 0.13$ \\
Nitrogen free extract & $57.56 \pm 0.07$ \\
Total carbohydrate & $63.91 \pm 0.13$ \\
\hline
\end{tabular}




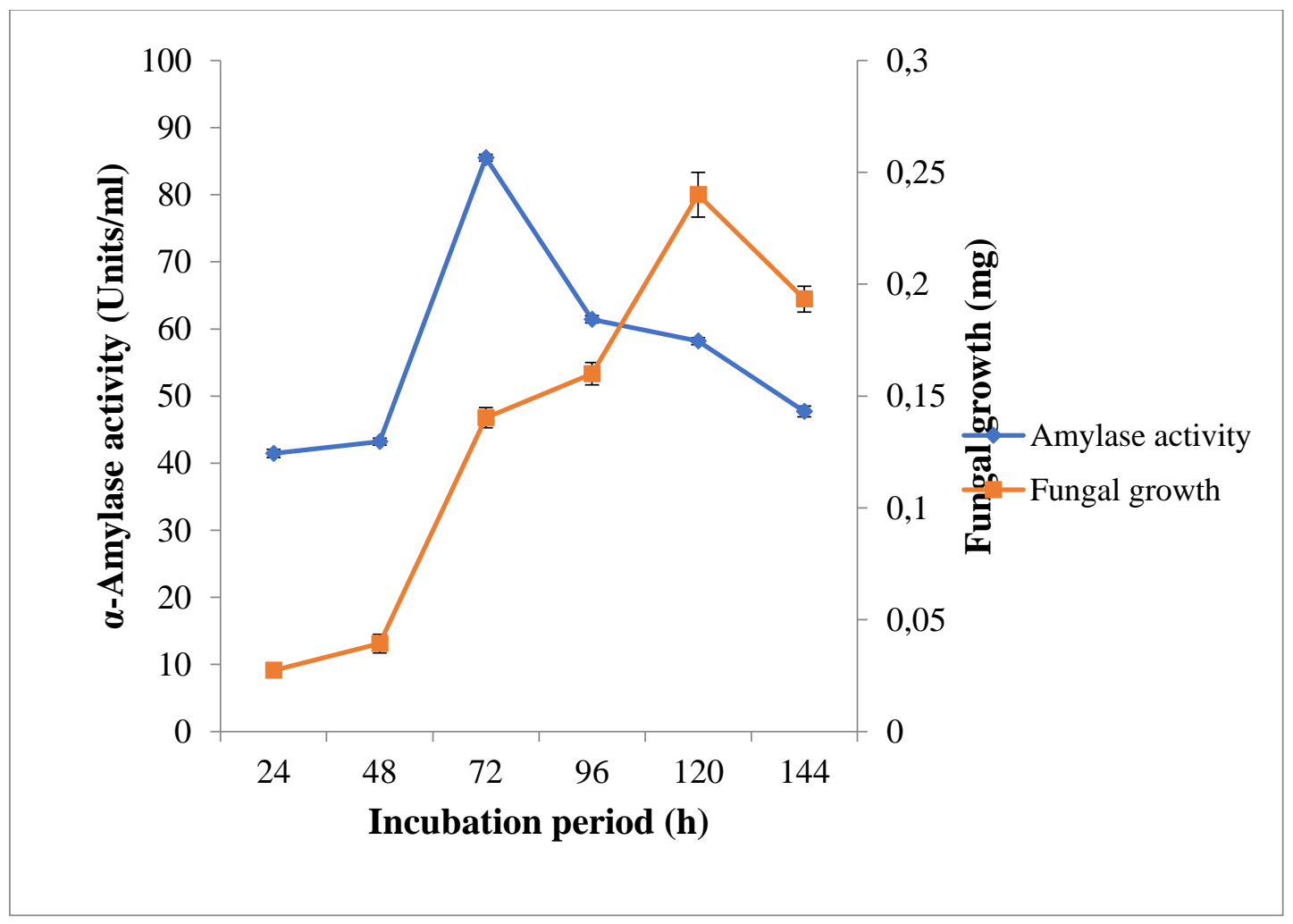

Figure 2: Effect of incubation period on fungal growth and $\alpha$-amylase production.

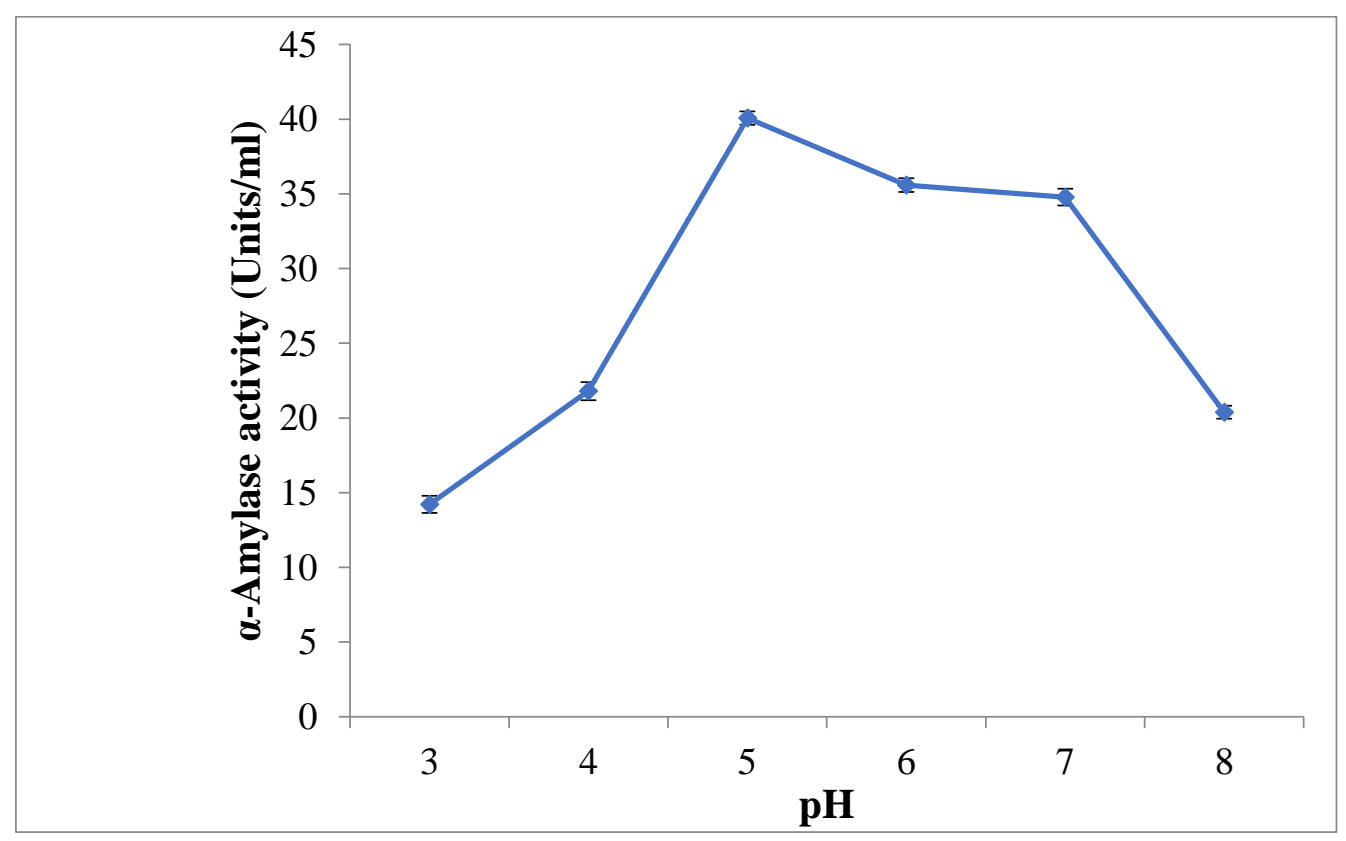

Figure 3: Effect of $\mathrm{pH}$ on $\alpha$-amylase production from A. flavus S2-OY. 


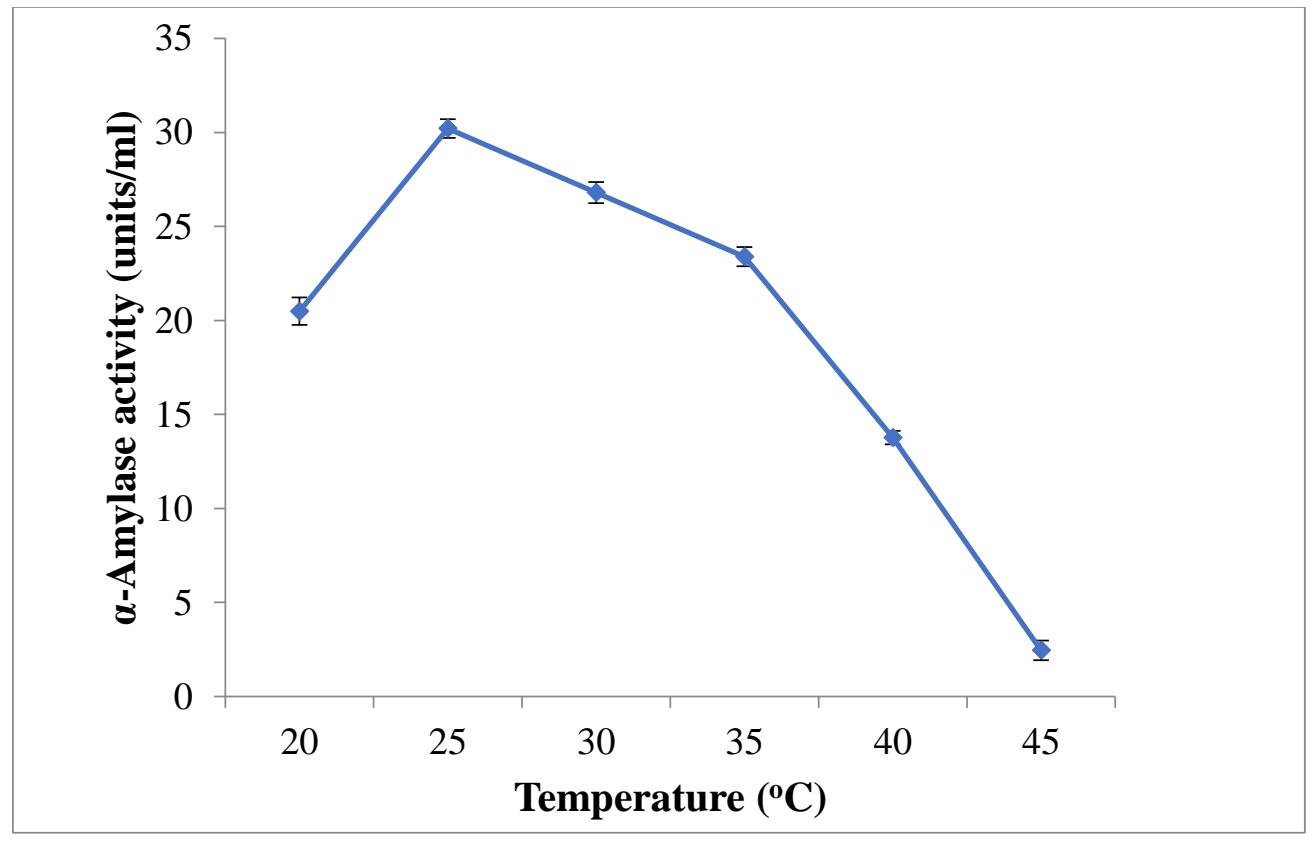

Figure 4: Effect of temperature on $\alpha$-amylase production from A. flavus S2-OY.

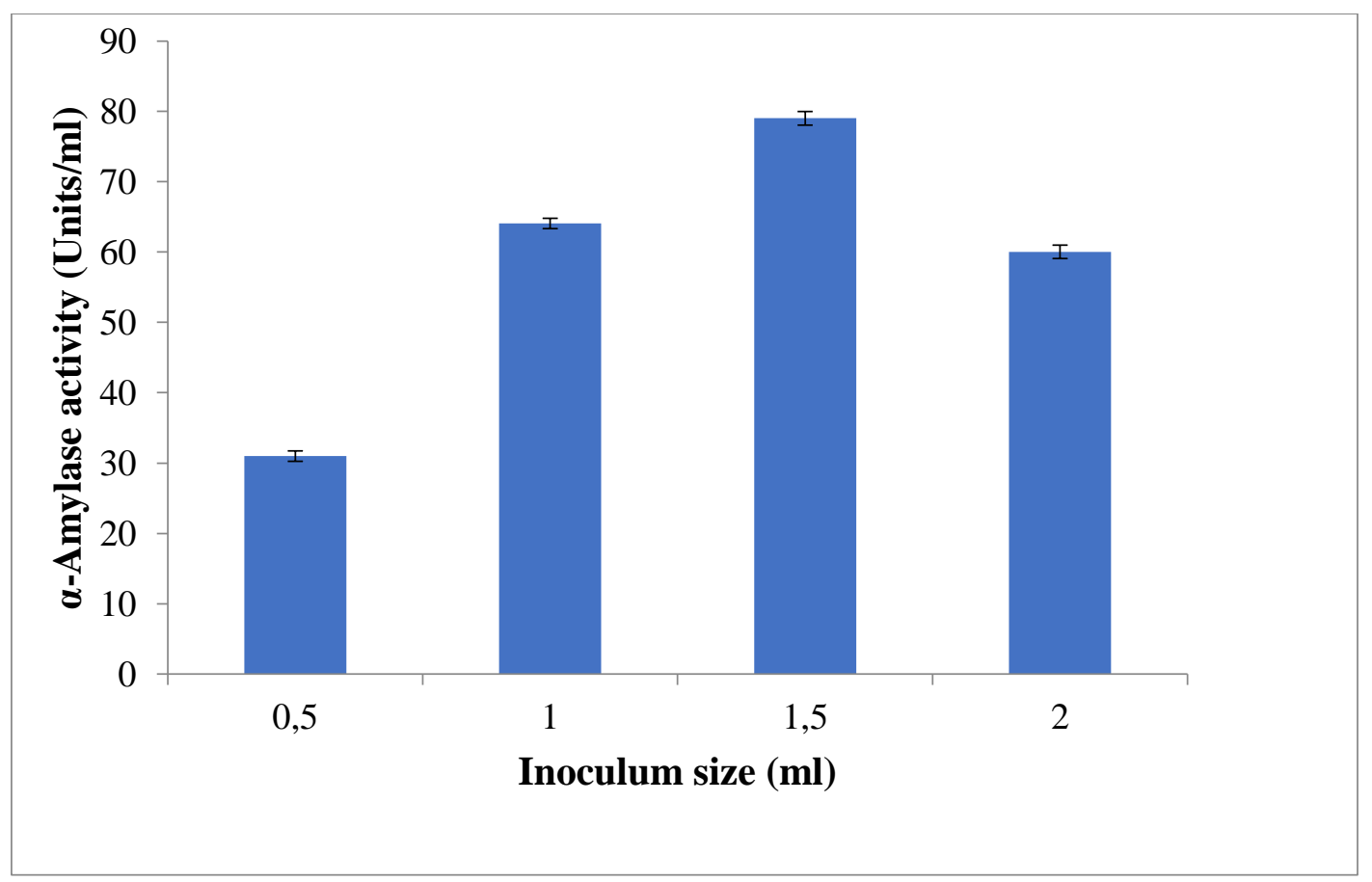

Figure 5: Effect of inoculum size on $\alpha$-amylase production from A. flavus S2-OY. 


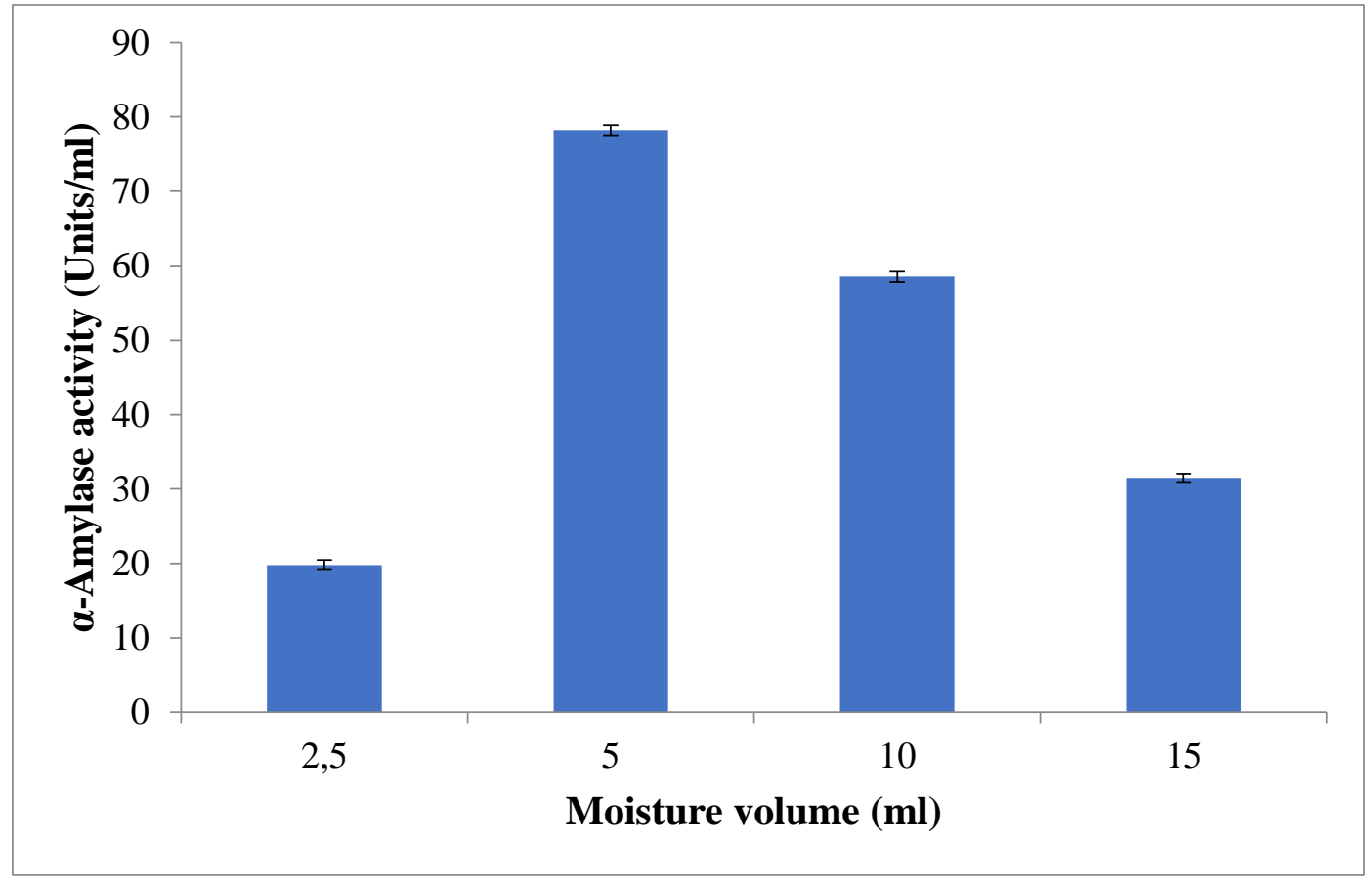

Figure 6: Effect of moisture volume on $\alpha$-amylase production from A. flavus S2-OY.

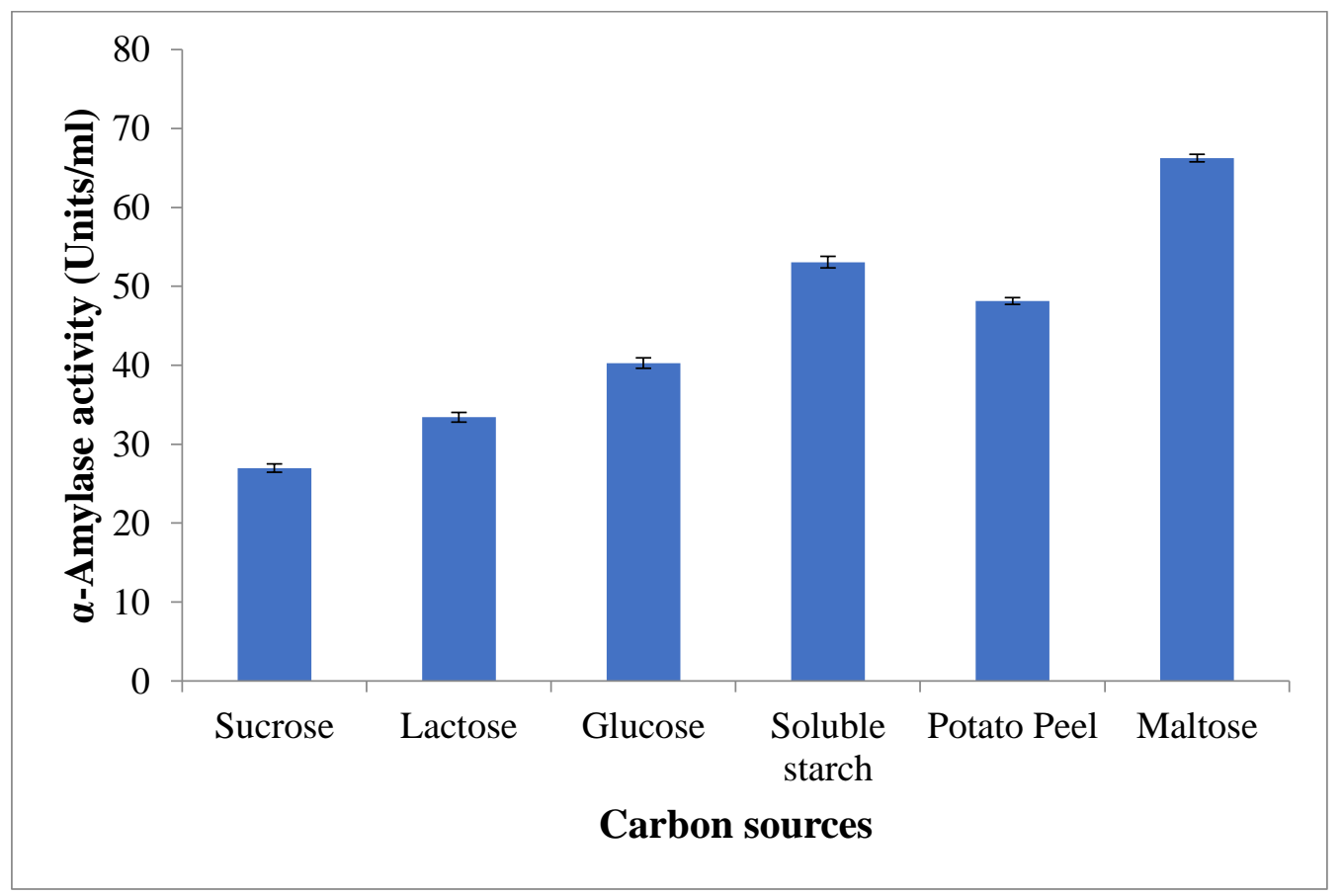

Figure 7: Effect of carbon sources on $\alpha$-amylase production from A. flavus S2-OY. 


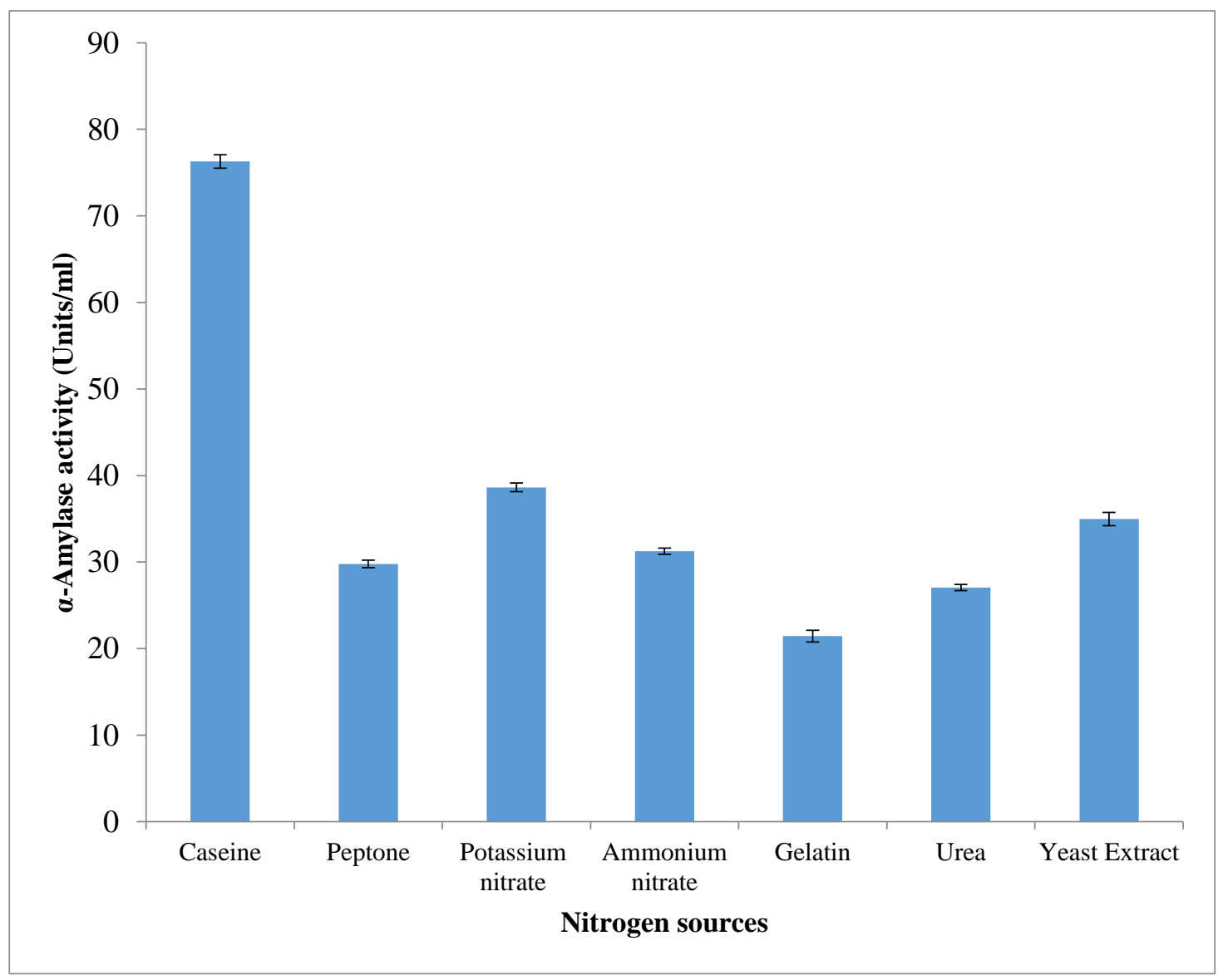

Figure 8: Effect of nitrogen sources on $\alpha$-amylase production from A. flavus S2-OY.

\section{DISCUSSION}

In this study, six fungal strains were isolated from the soil of a cassava waste dumpsite at Tonkere village, Ile-Ife, Osun State, Nigeria. The six isolates were presumptively identified by phenotypic method as two Aspergillus species and one species each of Rhizopus, Trichocladium, Neosartorya and Ascodermis. Several workers had reported the occurrence of amylolytic fungi in the soil, especially of starch processing sites, describing the soil as a repository of amylase-producing microorganisms (Egbere et al., 2014; Ogbonna et al., 2014; Ferreira et al., 2015).

The fungal isolate with the most appreciable $\alpha$-amylolytic activity was selected for further studies. It was presumptively identified as a strain of Aspergillus sp. 1. The identity of the selected fungus was confirmed by molecular characterization, using the ITS rRNA gene sequencing, as Aspergillus flavus S2-OY. Several strains of Aspergillus spp. have been implicated in $\alpha$-amylase production (Ayanda et al., 2013; Ogbonna et al., 2014; Ali et al., 2017; Karim et al., 2018).

The most appreciable enzyme production was observed with the use of potato peel as substrate. There are several reports of the use of agricultural wastes as cheap substrates for microbial $\alpha$-amylase production (Xu et al., 2008; Murthy et al. 2009; Jahir and Sachin, 2011). The selection of an agricultural waste as substrate for enzyme production depends upon several factors mainly related with cost and availability of the substrate. The 
solid substrate not only supplies the nutrients to the microbial culture growing in it but also serves as anchorage for the cells (Nimkar et al., 2010). Potato peel wastes contribute the major industrial food waste discarded in the environment, arising from potato processing and home wastes (Shukla and Kar, 2006; Schieber et al., 2009). Biotechnological applications of potato peel wastes are interesting not only from the point of view of low-cost substrate, but also in solving problems related to their disposal (Schieber et al., 2009).

The result of the proximate chemical analysis of the potato peel used in this study was similar to that of USDA (2008) that reported that in every $100 \mathrm{~g}$ of raw potato peel, the following nutrients can be found; $1.61 \mathrm{~g}$ ash, $0.1 \mathrm{~g}$ total fat, $2.57 \mathrm{~g}$ protein, $2.5 \mathrm{~g}$ total dietary fiber and $83.29 \mathrm{~g}$ water. However, a slight variation in the findings of the current research could be as a result of environmental conditions of the soil in which the potato tubers were grown.

Filamentous fungi are best adapted for solid substrate fermentation (SSF). The hyphal mode of fungal growth and their good tolerance to low water activity and high osmotic pressure conditions make fungi efficient and competitive in natural micro flora for bioconversion of solid substrates (Sethi et al., 2016). Traditionally, submerged fermentation has always been deployed for $\alpha$-amylase production. However, solid substrate fermentation method is gradually being utilized for this purpose due to advantages such as simple technique, superior and high volumetric productivity, low capital investment, low catabolite repression, marginal end-product inhibition, low energy requirement, simple fermentation equipment requirement, less water output and better product recovery (Xu et al., 2008; Ferreria et al., 2015).

Alpha amylase production from the study fungus increased from $24 \mathrm{~h}$ and peaked at $72 \mathrm{~h}$ incubation period, after which there was a steady decline in enzyme production. A similar finding was reported by Nwagu and Okolo (2011), in which the test fungus also exhibited maximum extracellular amylase production after $72 \mathrm{~h}$ fermentation period. The decline in enzyme production was most likely due to reasons such as depletion of nutrients in the culture medium, production of other byproducts of metabolism and enzyme denaturation (Sindhu et al., 2009; Haq et al., 2012). Fungal growth was observed to have continued even with the decrease in enzyme production within the period of incubation. This could be as a result of the availability of nutrients in the fermentation medium and the fungus still being in its exponential stage of growth.

Aspergillus flavus S2-OY exhibited maximum $\alpha$-amylase production at $\mathrm{pH}$ 5.0. An optimum $\mathrm{pH}$ of 5.0 was similarly observed for $\alpha$-amylase production from A. niger (Renato and Nelson (2009) and Penicillium purpurogenum (Silva et al., 2011). However, pH 5.5 was observed to be the optimum for $\alpha$ amylase production from a strain of $A$. flavus (Ali et al., 2017). Hydrogen ion concentration $(\mathrm{pH})$ plays important role in microbial growth by affecting enzyme secretion and product stability in the fermentation medium (RomeroGomez et al., 2000).

Alpha amylase production was observed to be optimum at an incubation temperature of $25^{\circ} \mathrm{C}$ while at temperatures above this, production declined and ceased at $45{ }^{\circ} \mathrm{C}$. This result is similar to optimum temperature of $28{ }^{\circ} \mathrm{C}$ observed for $\alpha$-amylase production from A. flavus (Ali et al., 2017). During enzyme production at differing temperatures, stabilization of metabolic network is supposedly by the folding of proteins of the metabolic network itself, most probably by acquiring chaperones (Borges and Ramos, 2005). Temperature above $45{ }^{\circ} \mathrm{C}$ results in moisture loss of the substrate, which affects metabolic activities of fungi, and results in reduced growth and $\alpha$-amylase production (Sindhu et al., 2009).

The use of maltose as carbon source led to maximum level of enzyme production, followed by soluble starch and potato peel. Shalini and Majoj (2014) reported similar 
finding for $\alpha$-amylase production from Bacillus amyloliquifaciens. Carbon sources represents the energetic sources that are available for the growth of and metabolite production by microorganisms (Balkan et al., 2011).

Among the different nitrogen sources, casein gave maximum production of $\alpha$-amylase from A. flavus S2-OY. The presence of organic nitrogen sources such as casein, urea and peptone has been reported to enhance aamylase enzyme production by microorganisms (Anto et al., 2006).

The best inoculum size for $\alpha$-amylase production was $1.5 \mathrm{ml}$ of fungal spore suspension. Balkan and Ertan (2010) reported that inoculum concentration $2.5 \mathrm{ml}$ of Penicillium brevicompactum gave the maximum production of $\alpha$-amylase. Higher inoculum concentration will increase the moisture content to a significant extent. The free excess liquid present in an unabsorbed form will therefore give rise to an additional diffusion barrier together with that imposed by the solid nature of the substrate and lead to a decrease in growth and enzyme production (Balkan et al., 2011). On the other hand, low inoculum size requires longer time for the cells to multiply to sufficient number to utilize the substrate and produce the desired product (Ramachandran et al., 2004). Further increase in inoculum sizes result in decreased enzyme synthesis, indicating that limitation of nutrients occurred due to the increased microbial activity.

Moisture is among the basic growth requirements of microorganisms. The most suitable moisture content needed for maximum $\alpha$-amylase production in this study was $5.0 \mathrm{ml}$ of minimal salt solution. The optimum moisture content for growth and substrate utilization depends upon the organism and water-holding capacity of substrate used for cultivation (Balkan et al., 2011).

\section{Conclusion}

The use of $\alpha$-amylase in the food, baking, textile, detergent and pharmaceutical industries has been increasing with the growing demands of population. This study indicated the feasibility of the use of potato peel as an alternative substrate for $\alpha$-amylase production from Aspergillus sp. via the solid substrate fermentation technique. Optimal conditions for maximum $\alpha$-amylase production from the fungus, isolated from the soil of a cassava waste dumpsite, were incubation period of 72 h, initial medium $\mathrm{pH}$ of 5.0 , temperature of 25 ${ }^{\circ} \mathrm{C}$, casein and maltose as best nitrogen and carbon sources, respectively, as well as $1.5 \mathrm{ml}$ inoculum size and $5.0 \mathrm{~mL}$ moisture content. This study has implications for the costeffective production of a biotechnologicallyimportant enzyme, as well as mitigation of environmental pollution problems through effectual management of agro-industrial wastes.

\section{COMPETING INTERESTS}

The authors declare that they have no competing interests.

\section{AUTHORS' CONTRIBUTIONS}

Author OO conceived and monitored the stages of the research; Author VOA ran the laboratory procedures, did the literature search and statistical analysis; Author OO wrote the manuscript; Both authors read and approved the manuscript for publication.

\section{ACKNOWLEDGEMENTS}

Authors appreciate the staff of the Laboratory of the Department of Microbiology, Obafemi Awolowo University, Ile-Ife, Nigeria, for provision of reagents and offer of required technical assistance for the study.

\section{REFERENCES}

Acourene S, Ammouche A. 2012. Optimization of ethanol, citric acid, and $\alpha$-amylase production from date wastes by strains of Saccharomyces cerevisiae, Aspergillus niger and Candida guilliermondii. Journal of Industrial Microbiology and Biotechnology, 39(5): 759-66. DOI: 
http://dx.doi.org/10.1007/s10295-0111070-0

Adejuwon AO, Oluduro AO, Agoola FK, Olutiola PO, Segal SJ. 2015. Expression and characterization of $\alpha$-amylase from Penicillium citrinum with bread as growth substrate. International Journal of Biological and Chemical Sciences, 9(4): 2136-2151.

DOI: http://dx.doi.org/10.4314/ijbcs.v9i4.34

Ahmed I, Zia MA, Azhar M, Akram Z, Naveed T, Nowrouzi A. 2016. Bioprocessing of citrus waste peel for induced pectinase production by Aspergillus niger, its purification and characterization. Journal of Radiation Research and Applied Science, 9(2): 148-154. DOI: http://dx.doi.org/10.1016/j.jrras.2015.11. 003

Ajayi AA, Adejuwon AO, Obasi CK, Olutiola PO, Peter-Albert CF. 2014. Amylase activity in culture filtrate of Aspergillus chevalieri. International Journal of Biological and Chemical Sciences, 8(5): 2174-2182.

DOI: http://dx.doi.org/10.4314/ijbcs.v8i5.21

Ali EH, El-Nagdy MA, Al-Garni SM, Ahmed MS, Rawaa AM. 2017. Enhancement of alpha amylase production by Aspergillus flavus AUMC 11685 on mandarin (Citrus reticulata) peel using submerged fermentation. European Journal of Biological Research, 7(3): 154-164. DOI: http://dx.doi.org/10.5281/zenodo.818271

AOAC. 2005. Official Methods of Analysis of the Association of Official Analytical Chemists (18th Edn). AOAC: Gaithersburg, Md., USA.

Anto H, Trivedi U, Patel K. 2006. Alpha amylase production by Bacillus cereus MTCC 1305 using solid-state fermentation. Food Technology and Biotechnology, 44(2): 241-245.

Ayanda OI, Ajayi AA, Olasehinde GI, Dare OT. 2013. Isolation, characterization and extracellular enzyme detection of microbial isolates from deteriorated apple (Macus domestica) fruits. International
Journal of Biological and Chemical Sciences, 7(2): 641-648. DOI: http://dx.doi.org/10.4314/ijbcs.v7i2.20.

Balkan B, Balkan S, Ertan F. 2011. Optimization of parameters for $\alpha$-amylase production under solid state fermentation by Trichothecium roseum. Romanian Biotechnological Letters, 16(5): 6591-6600.

Balkan B, Ertan F. 2010. The production of a new fungal alpha-amylase degraded the raw starch by means of solid-state fermentation. Preparative Biochemistry and Biotechnology, 40(3): 213-228. DOI: http://dx.doi.org/10.1080/10826068.2010 .488549

Borges JC, Ramos CHI. 2005. Protein folding assisted by chaperones. Protein and Peptide Letters, 12: 257-261. DOI: https://doi.org/10.2174/09298660535871 65

Chimata MK, Sasidhar P, Challa S. 2010. Production of extracellular amylase from agricultural residues by a newly isolated Aspergillus species in solid state fermentation. African Journal of Biotechnology, 9(32): 5162- 5169.

Dhanya G, Madhavan NK, Swetha S, Pandey A. 2009. Immobilized bacterial $\alpha$ amylases for effective hydrolysis of raw starch and soluble starch. Food Research International, 42(4): 436-442. DOI: http://dx.doi.org/10.1016/j.foodres.2009. 02.008

Di Donato P, Fiorentino G, Anzelmo G, Tommonaro G, Nicolaus B, Poli A. 2011. Re-use of vegetable wastes as cheap substrates for extremophile biomass production. Waste Biomass Valorization, 2: 103-111. DOI: http://dx.doi.org/10.1007/s12649-0119062-x

Egbere OJ, Mang GP, Pondei JO, Yakubu AD, Dayok O. 2014. Screening of Cellulolytic and Amylolytic Fungi Associated with Corncobs in Refuse Dumps within Jos, Nigeria. International Journal of 
Microbiology and Immunology Research, 3(4): 52-57.

Ferreira OE, Montijo NA, Martin E, Mutton MJ. 2015. Production of $\alpha$-amylase by solid state fermentation by Rhizopus oryzae. African Journal of Biotechnology, 14(7): 662-628. DOI: https://doi.org/10.5897/AJB2014.14296.

Gaddeyya G, Niharika PS, Bharathi P, Kumar KPR. 2012. Isolation and Identification of Soil Microflora in Different Crops Field at Salur Mandal. Advanced Applied Science Research, 3: 2020-2026.

Haq I, Hameed U, Mhamood Z, Javed MM. 2012. Solid state fermentation for the production of alpha-amylase by Paenibacillus amylolyticus. Pakistani Journal of Biological Science, 44: 341346.

Hill SL, Tan JS, Ling TC, Ariff AB. 2012. Pullulanase: Role in starch hydrolysis and potential industrial applications. Enzyme Research, 2012: 14 pages. Article ID 921362. DOI: http://dx.doi.org/10.1155/2012/921362

Jahir AK, Sachin KY. 2011. Production of alpha amylases by Aspergillus niger using cheaper substrates employing solid state fermentation. International Journal of Plant, Animal and Environmental Sciences, 1(3): 231-290.

Karim KMR, Hussaini A. Sing NN, Sinang FM. Rosian HA, Hussain H. 2018. Purification of an alpha amylase from Aspergillus flavus NSH9 and molecular characterization of its nucleotide gene sequence. 3 Biotech, 8(4): 204. DOI: http://dx.doi.org/10.1007/s13205-0181225-z

Khan JA, Yadav SK. 2011. Production of $\alpha$ amylase by Aspergillus niger using cheaper substrates employing solid state fermentation. International Journal of Plant, Animal and Environmnetal Science, 1(3): 100-108.

Kirankumar V, Ravi Sankar N, Shailaja R, Saritha K, Siddhartha E, Ramya S, Giridhar D, Sahaja RV. 2011. Purification and Characterization of $\alpha$-Amylase Produced by Aspergillus niger Using Banana Peels. Journal of Cell and Tissue Research, 11(2): 2775-2780.

Maity S, Mallik S., Basuthakur R, Gupta S. 2015. Optimization of solid-state fermentation conditions and characterization of thermostable alpha amylase from Bacillus subtilis (ATCC 6633). Journal of Bioprocess and Biotechnology, 5: 1-7.

Miller GL. 1959. Use of Dinitrosalicylic Acid Reagent for Determination of Reducing Sugar. Analytical Chemistry, 31: 426-42. DOI: http://doi.org/10.1021/ac60147a030

Murthy PS, Naidu MM, Srinivas P. 2009. Production of $\alpha$-amylase under solid substrate fermentation utilizing coffee waste. Journal of Chemistry Technology and Biotechnology, 84: 1246-1249. DOI: http://dx.doi.org/10.1002/jctb.2142

Nimkar MD, Deogade NG, Kawale M. 2010. Production of alpha-amylase from Bacillus subtilis and Aspergillus niger using different agro waste by solid state fermentation. Asian Journal of Biotechnological Research, 1: 23-28.

Nwagu TN, Okolo BN. 2011. Extracellular Amylase Production of a Thermotolerant Fusarium sp. Isolated from Eastern Nigerian soil. Brazilian Archive of Biology and Technology, 54(4): 649-658. DOI: http://dx.doi.org/10.1590/S151689132011000400002

Ogbonna, CN, Okpokwu NM, Okafor CU, Onyia CE. 2014. Isolation and screening of amylase-producing fungi obtained from garri processing site. International Journal of Biotechnology and Food Science, 2(6): 88-93.

Oyeleke SB, Ibrahim AD, Manga SB, Rabah AB, Auta H, Ladan F. 2011. Production of bacterial amylase by Bacillus species isolated from rice husk dumpsites in Sokoto metropolis, Nigeria. International Journal of Biological and Chemical Sciences, 5(1): 380-385. 
Puri S, Arora M, Sarao L. 2013. Production and Optimization of Alpha Amylase and Glucoamylase using Aspergillus oryzae under Solid State Fermentation. International Journal of Research in Pure and Applied Microbiology, 3(3): 83-88.

Reddy NS, Nimmagada A, Sambasiva Rao KRS. 2003. An overview of the microbial $\alpha$-amylase family. African Journal of Biotechnology, 2: 645-648. DOI: http://dx.doi.org/10.5897/AJB2003.0001119

Renato PR, Nelson PG. 2009. Optimization of amylase production by Aspergillus niger in solid- state fermentation using sugarcane bagasse as solid support material. World Journal of Microbiology and Biotechnology, 25(11): 1929-1939. DOI: http://dx.doi. org/10.1007/s11274009-0091-6

Romero-Gomez SJ, Augur C, ViniegraGozalez G. 2000. Invertase production by Aspergillus niger in submerged and solid-state fermentation. Biotechnology Letters, 22: 1255-1258. DOI: http://dx.doi.org/10.1023/A:1005659217 932

Roses RP, Guerra NP. 2009. Optimization of amylase production by Aspergillus niger in solid state fermentation using sugarcane bagasse as solid support material. World Journal of Microbiology and Biotechnology, 25: 1929-1939. DOI: http://dx.doi.org/10.1007/s11274-0090091-6

Schieber A, Marleny D, Saldana A. 2009. Potato peels: A Source of Nutritionally and Pharmacologically Interesting Compounds-A review. Food, 3(2): 23-29.

Sethi BK, Jana A, Nanda PK, DasMohapatra RK, Sahoo SL, Patra JK. 2016. Production of $\alpha$ - amylase by Aspergillus terreus NCFT 4269.10 using pearl millet and its structural characterization. Frontiers in Plant Science, 7: $639 . \quad$ DOI: http://dx.doi.org/10.3389/fpls.2016.0063 9
Sethi BK, Nanda PK, Sahoo S. 2016. Characterization of biotechnologically relevant extracellular lipase produced by Aspergillus terreus NCFT 4269.10. Brazilian Journal of Microbiology, 47(1): 143-149. DOI: http://dx.doi:10.1016/j.bjm.2015.11.026

Shalini RAI, Majoj KS. 2014. Optimization of thermostable alpha-amylase production via mix agricultural-residues and Bacillus amyloliquefaciens. Notulae Scientia Biologicae, 6(1): 105-111. DOI: http://dx.doi.org/10.15835/nsb.6.1.9138

Shukla J, Kar R. 2006. Potato Peel as a Solid Substrate for Thermostable $\alpha$-amylase Production by Thermophilic bacillus Isolates. World Journal of Microbiology and Biotechnology, 22: 417-422. DOI: http://dx.doi.org/10.1007/s11274-0059049-5

Silva T, Oliveira M, Somera A, Jorge J, Terenzi HF, Polizeli MD, Guimaraes LHS. 2011. Thermostable saccharogenic amylase produced under submerged fermentation by filamentous fungus Penicillium purpurogenum. Brazilian Journal of Microbiology, 42: 1136-

1140.

DOI: http://dx.doi.org/10.1590/S151783822011000300035

Simair AA, Qureshi AS, Khushk I, Ali CH, Lashari S, Bhutto MA, Mangrio GS and Lu C. 2017. Production and Partial characterization of $\alpha$-amylase enzyme from Bacillus sp. BCC 01- $50 \quad$ and potential applications. BioMed Research International 2017, Article ID 9173040:9. DOI: http://dx.doi.org/10.1155/2017/9173040

Sindhu R, Suprabha GN, Shashidhar S. 2009. Optimization of process parameters for the production of $\alpha$-amylase from Penicillium janthinellum (NCIM 4960) under solid state fermentation. African Journal of Microbiology Research, 3(9): 498-503.

Singh RK, Kumar S, Surendra K. 2009. Production of $\alpha$-amylase from agriculture 
by production by Humicola lanuginosus in solid state fermentation. Current Trends in Biotechnology and Pharmacology, 3(2): 19-29.

Singh V, Haque S, Niwas R, Srivastava A, Pasupuleti M, Tripathi CKM. 2017. Strategies for fermentation medium optimization: An in-depth review. Frontiers in Microbiology, 7: 2087. DOI: http://dx.doi.org/10.3389/fmicb.2016.02 087.

USDA. 2008. National Nutrient Database. Available Online. http//www.nal.usda.gov

Varga J, Samson RA. 2008. Aspergillus in the Genomic Era. Wageningen Academic Publishers: Wageningen. DOI: https://doi.org/10.3920/978-90-8686635-9

White TJ, Bruns TD, Lee SB, Taylor JW. 1990. Amplification and direct sequencing of fungal ribosomal RNA genes for phylogenetics. In PCR Protocols: A Guide to Methods and Applications, Innis MA, Gelfand DH, Sninsky JJ, White TJ (eds). Academic Press: London, UK; 315322.

Xu H, Sun L, Zhao D, Zhang B, Shi Y, Wu Y. 2008. Production of $\alpha$-amylase by Aspergillus oryzae in solid substrate fermentation using spent brewing grains as substrate. Journal of Science and Food Agriculture, 88: 529-535. DOI: https://doi.org/10.1002/jsfa.3118

Zambare V. 2010. Solid substrate fermentation of Aspergillus oryzae for Glucoamylase production on agro-residues. International Journal of Life Science, 4: 16-25.

DOI: https://doi.org/10.3126/ijls.v4i0.2892. 